\title{
Distribution and ecology of non-marine ostracods (Crustacea, Ostracoda) from Friuli Venezia Giulia (NE Italy)
}

\author{
Valentina PIERI, Koen MARTENS ${ }^{1)}$, Fabio STOCH $^{2)}$ and Giampaolo ROSSETTI* \\ Department of Environmental Sciences, University of Parma, Viale G.P. Usberti 33A, 43100 Parma, Italy \\ ${ }^{1)}$ Royal Belgian Institute of Natural Sciences, Freshwater Biology, Vautierstraat 29, 1000 Brussels, Belgium \\ ${ }^{2)}$ Formerly Technical Secretariat for Protected Areas, Ministry for Environment, Territory Protection and Sea; \\ present address: Via Sboccatore 3/27, 00069 Trevignano Romano, Roma, Italy \\ *e-mail corresponding author: giampaolo.rossetti@unipr.it
}

\begin{abstract}
From August 1981 to July 2007, 200 inland water bodies were sampled to gather information on the Recent ostracod fauna of Friuli Venezia Giulia (NE Italy). A total of 320 samples were collected from surface, interstitial and ground waters. Whenever possible, ostracod identification was performed at species level based on the morphology of both valves and limbs. Seventy-four taxa in 30 genera belonging to 9 different families (Darwinulidae, Candonidae, Ilyocyprididae, Notodromadidae, Cyprididae, Limnocytheridae, Cytheridae, Leptocytheridae and Xestoleberididae) were identified. The maximum number of taxa per site was seven. The most common species was Cypria ophthalmica (133 records), followed by Cyclocypris ovum (86 records), C. laevis (49 records), Cypridopsis vidua (40 records) and Notodromas persica (28 records). Of particular relevance is the occurrence of six species new to Italy: Microdarwinula zimmeri, Penthesilenula brasiliensis, Fabaeformiscandona wegelini, Pseudocandona semicognita, Candonopsis scourfieldi, and C. mediosetosa. Scanning electron microscopy images of valves are provided for most of the described taxa. Geographical distribution of ostracods and their occurrence in relation to environmental variables were examined. The results of this study indicate that Friuli Venezia Giulia hosts a very diverse ostracod fauna, representing a significant proportion of all ostracod taxa known thus far from Italy.
\end{abstract}

Key words: inland waters, Recent ostracods, taxonomy, biodiversity, ecology, SEM.

\section{INTRODUCTION}

Ostracods (class Ostracoda) are one of the most diverse groups of living crustaceans. There are close to 2000 subjective species and about 200 genera of Recent non-marine Ostracoda (Martens et al. 2008). All Recent freshwater ostracods belong to the order Pocodocopida (Meisch 2000). Ostracods are very common in most inland waters, where they abound in the benthic and periphytic animal communities, but they also occur in marine, interstitial and even (semi-) terrestrial environments.

Unlike other European countries (e.g., Germany, Belgium and France among others), in Italy the research on Recent freshwater ostracods does not have a solid tradition, and available data mostly rely on occasional investigations. The first studies on taxonomy and ecology of Cyprididae were carried out by Masi (1905, 1909 ) at the beginning of $20^{\text {th }}$ century. A key contribution was the compilation of the Italian checklist by Ghetti \& McKenzie (1981), although the inadequacy of the taxonomic descriptions and the incomplete data on species distribution constitute a serious limitation to its practical use. Only recently detailed accounts on taxonomy, ecology and geographic distribution of Italian ostracods have been published, in particular for areas located in the northern part of the peninsula and for Sicily
(Rossi et al. 2003; Mezzanotte \& Sambugar 2004; Rossetti et al. 2004, 2005, 2006; Pieri 2007; Pieri et al. 2006, 2007).

The aims of this study are to provide a detailed faunal inventory of Recent ostracods from freshwater habitats of the Friuli Venezia Giulia region (NE Italy) and investigate their distributional patterns in relation to environmental factors. In addition, the new data are compared to previous investigations on Recent ostracods carried out in this region by Stoch $(1985,1992$, 1993, 1995, 1996, 1997, 2003, 2004), Stoch \& Dolce (1994), and Meisch (2000). Scanning Electron Microscope images of ostracod valves are also offered.

\section{MATERIALS AND METHODS}

Located at the north-eastern border of the Italian peninsula (Fig. 1), Friuli Venezia Giulia $\left(7844 \mathrm{~km}^{2}\right)$ is a region characterised by a strong south-north altitudinal gradient from the Adriatic Sea to the Julian and Carnic Alps ridge (up to $2780 \mathrm{~m}$ a.s.l. of the mount Coglians) and by a variety of climatic, geological and land-use conditions. The study area, that has encompassed three provinces (Gorizia, Pordenone, and Udine) of the region (Fig. 2), is rich in both surface and ground waters. Samples were collected between August 1981 and July 2007 from 200 sites located at an altitude ranging from 1 to $1950 \mathrm{~m}$ a.s.l. 


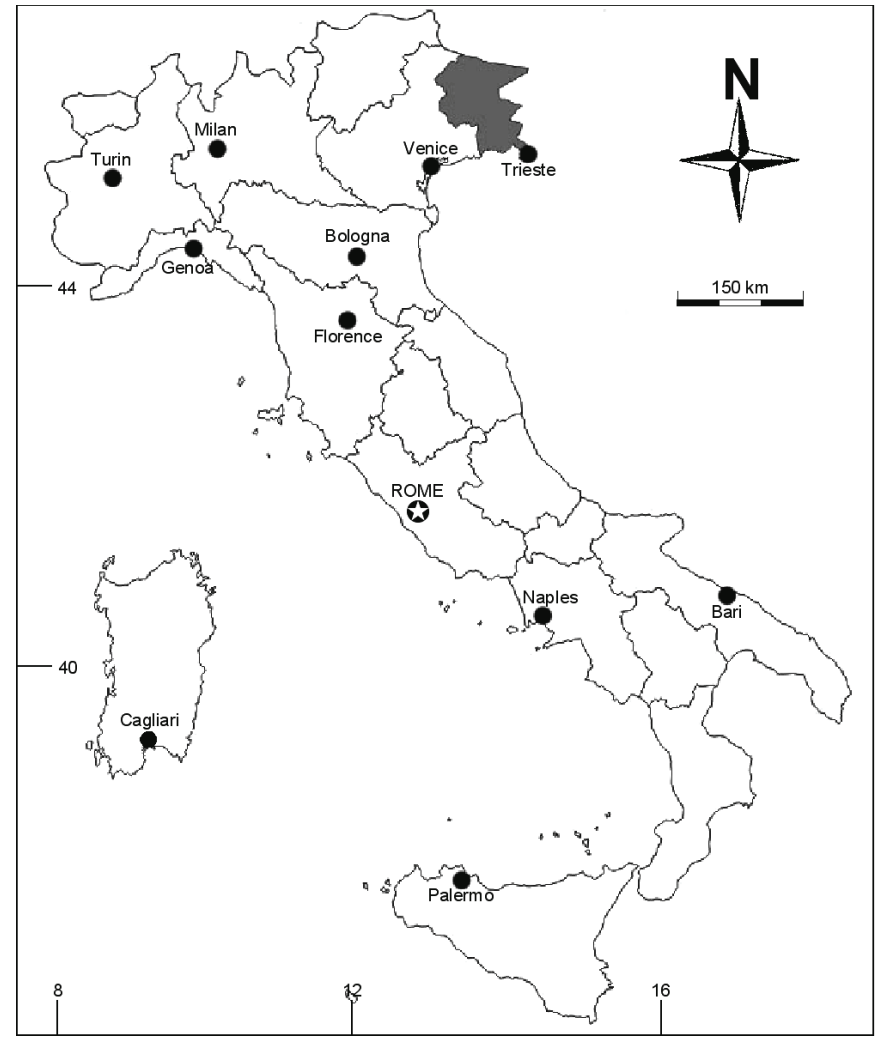

Fig. 1. Map of Italy. Friuli Venezia Giulia region is indicated in grey.
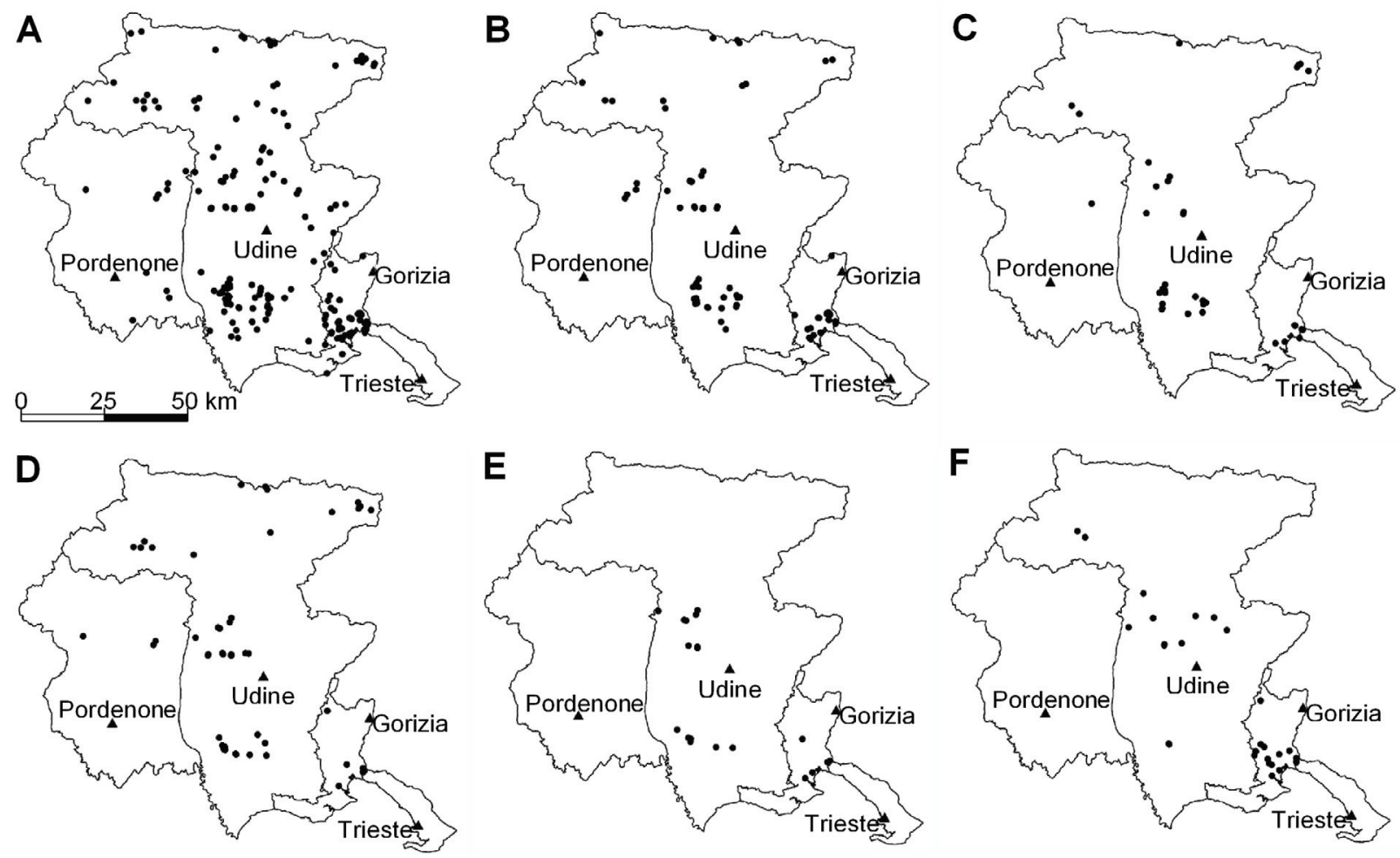

Fig. 2. Map of the Friuli Venezia Giulia region showing the sampling sites (A) considered in this study and distribution of the most frequent ostracod species (B: Cypria ophthalmica; C: Cyclocypris laevis; D: Cyclocypris ovum; E: Notodromas persica; F: Cypridopsis vidua). Some nearby sampling sites are indicated with a single spot. 

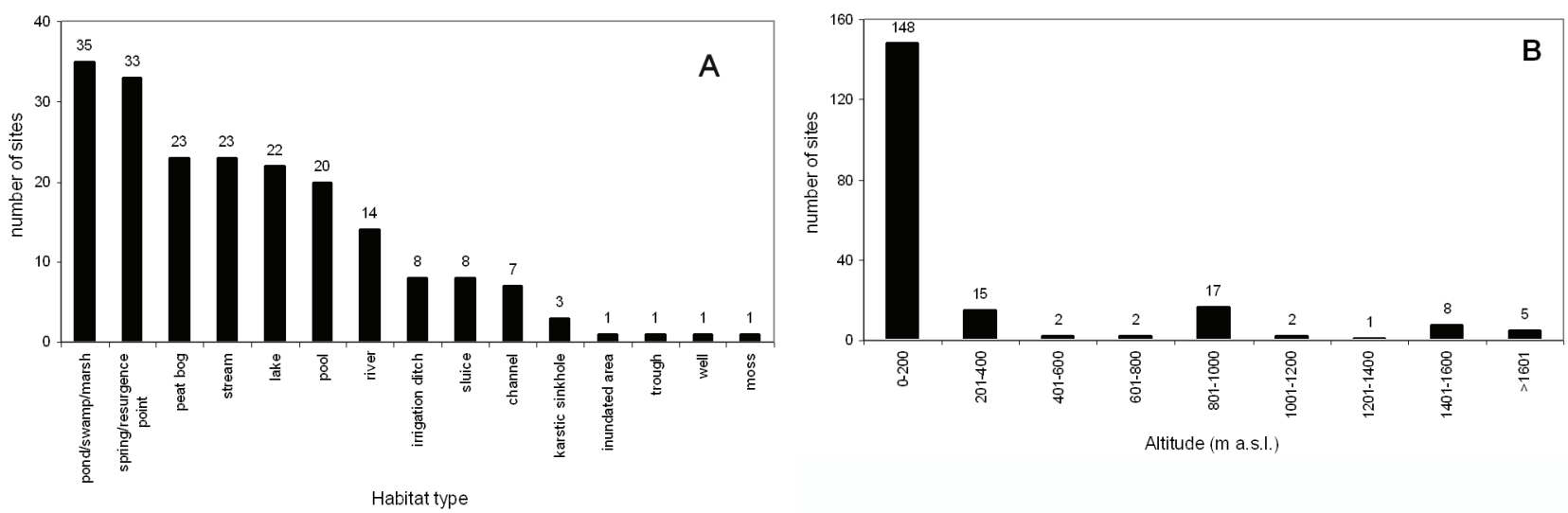

Fig. 3. Histograms showing the distribution of sampled sites by habitat typology (A) and altitude (B).

Qualitative ostracod samples were collected using a $100 \mu \mathrm{m}$ handnet or, from interstitial habitats, by a BouRouch pump (Bou \& Rouch 1967; Bou 1974) or using the Karaman-Chappuis method (Chappuis 1942). Altogether, 320 samples were collected. In 67 sites, the sampling was performed on different dates (2 to 4$)$. In 111 samples, water temperature, conductivity, $\mathrm{pH}$ and dissolved oxygen concentration were measured in situ using portable electronic probes (Hanna Instruments). The province with the highest number of sampling sites was Udine (135 sites), followed by Gorizia ( 55 sites), and Pordenone (10 sites) (Fig. 2). Sampling sites were chosen to possibly include the most common types of aquatic habitats (i.e., pools, ponds, peat bogs, springs and streams). The most sampled habitats were wetlands (Fig. 3A), and a large part of the sampling sites (148) was located below $200 \mathrm{~m}$ a.s.l. (Fig. 3B).

In the laboratory, living specimens were picked up under a binocular microscope and preserved in $80 \%$ ethanol. Only material allowing unambiguous identification (i.e., adults and last juvenile stages) was taken into account, although in few cases (i.e., Pseudocandona cf. insculpta, Cypridopsis cf. hartwigi, and Xestoleberis sp.) the specific allocation remained uncertain, due to either damaged specimens or scarce material. Both soft parts (dissected in glycerine and stored in sealed slides) and valves (stored dry in micropaleontological slides) were checked for the taxonomic identification, using as reference the contribution by McKenzie (1977) for Xestoleberis, Meisch (1984, 1985) for Potamocypris, Petkovski \& Keyser (1992) for Leptocythere, Martens (1992) for Paralimnocythere, Baltanás et al. (1993) for Psychrodromus, González Mozo et al. (1996) for Herpetocypris, Meisch (1996) for Schellencandona, Rossetti \& Martens (1998) for the Darwinulidae, Pinto et al. (2005) for Microdarwinula zimmeri, and Meisch (2000) for the remaining taxa.

All the collected material was catalogued through a numerical code consisting of the letters "VP" followed by 4 digits and was deposited in the ostracod collection at the Department of Environmental Sciences, Univer- sity of Parma. For problematic specimens and for the most interesting records, photos of the valves were taken in the SEM laboratory of the Royal Belgian Institute of Natural Sciences in Brussels using a Philips XL-30 microscope. The following abbreviations were used in plates (see Appendix): L: left; R: right; V: valve; $\mathrm{Cp}$ : carapace; $\mathrm{dv}$ : dorsal view; vv: ventral view; lv: lateral view; iv: internal view; ev: external view.

In order to assess the relation between distribution of ostracods and environmental variables, a Canonical Correspondence Analysis (CCA) was performed using the statistical package CANOCO version 4.5 (ter Braak \& Šmilauer 2002). CCA was based on the correlation matrix of measured physical and chemical water variables after $\log (\mathrm{x}+1)$ transformation (except for $\mathrm{pH})$ to normalize the distributions. Only significant variables $(P \leq 0.05)$ were entered into the model through a forward stepwise procedure. Monte Carlo permutation tests (999 permutations) were used to assess the significance of the canonical axes and of the environmental variables that were selected in the forward selection procedure. Due to the tendency of rare forms to distort the analyses, taxa with a single record were excluded from ordinations.

\section{RESULTS}

Seventy-four taxa (53 identified at the species level) included in 30 genera and belonging to 9 different families (Darwinulidae, Candonidae, Ilyocyprididae, Notodromadidae, Cyprididae, Limnocytheridae, Cytheridae, Leptocytheridae and Xestoleberididae) were identified (Tab. 1; Plates 1-7, in Appendix). Ostracods were found in all the analysed samples, but in 11 samples only juvenile stages were present, while in two samples only empty valves were found. The most common species was Cypria ophthalmica (133 records) followed by Cyclocypris ovum (86 records), C. laevis (49 records), Cypridopsis vidua (40 records) and Notodromas persica (28 records) (Fig. 2). The genus with most identified species was Pseudocandona (12 taxa), followed by Candona and Potamocypris (both with 6 taxa). 
Tab. 1. List of ostracods known from Friuli Venezia Giulia. Taxon codes used for CCA (see Fig. 12) are reported in column A. Comparison between ostracod taxa found in this study (column B: number of sites - number of samples where each taxon was found) and in previous surveys carried out by Meisch (2000) and Stoch (1985, 1993, 1994, 1995, 1996, 1997, 2003, 2004) (column C). The habitat types in which each taxon was found are listed in column D (CA: cave; CH channel; FO: fountain; IA: inundated area; ID: irrigation ditch; KS: karstic sinkhole; LA: lake; MO: moss; PB: peat bog; PD: pond; PL: pool; RI: river; SL: sluice; SP: spring; ST: stream; TR: trough; WL: well; WD: wetland).

\begin{tabular}{|c|c|c|c|c|}
\hline & A & B & $\mathrm{C}$ & $\mathrm{D}$ \\
\hline \multicolumn{5}{|l|}{ Superfamily Darwinuloidea Brady \& Norman, 1889} \\
\hline \multicolumn{5}{|l|}{ Family Darwinulidae Brady \& Norman, 1889} \\
\hline \multicolumn{5}{|l|}{ Genus Darwinula Brady \& Robertson, 1885} \\
\hline Darwinula stevensoni (Brady \& Robertson, 1870) & & $3-3$ & & $\mathrm{CH}, \mathrm{PB}, \mathrm{PD}$ \\
\hline \multicolumn{5}{|l|}{ Genus Penthesilenula Rossetti \& Martens, 1998} \\
\hline Penthesilenula brasiliensis (Pinto \& Kotzian, 1961) & Pbras & $6-8$ & & LA, PB, SP \\
\hline \multicolumn{5}{|l|}{ Genus Microdarwinula Danielopol, 1965} \\
\hline Microdarwinula zimmeri (Menzel, 1916) & Mzimm & $4-8$ & & PB, PL \\
\hline \multicolumn{5}{|l|}{ Superfamily Cypridoidea s. str. Baird, 1845} \\
\hline \multicolumn{5}{|l|}{ Family Candonidae Kaufmann, 1900} \\
\hline \multirow{2}{*}{\multicolumn{5}{|c|}{$\begin{array}{c}\text { Subfamily Candoninae Kaufmann, } 1900 \\
\text { Genus Candona } \text { s. str. Baird, } 1845\end{array}$}} \\
\hline & & & & \\
\hline Candona $\mathrm{sp}$ & Cansp & $8-8$ & $\mathrm{X}$ & $\mathrm{CH}, \mathrm{LA}, \mathrm{PD}, \mathrm{PL}, \mathrm{SL}, \mathrm{SP}$ \\
\hline Candona candida (O. F. Müller, 1776) & & $8-8$ & & LA, PD, RI, ST \\
\hline Candona gr. neglecta & & $3-3$ & & LA, PD, RI \\
\hline Candona neglecta Sars, 1887 & Cnegl & $6-10$ & & SP \\
\hline Candona cf. neglecta & Ccfne & $2-3$ & & SP \\
\hline Candona angulata Müller, 1900 & & $1-1$ & & PD \\
\hline \multicolumn{5}{|l|}{ Genus Fabaeformiscandona Krstić, 1972} \\
\hline Fabaeformiscandona sp. & & $2-2$ & & PL, SL \\
\hline Fabaeformiscandona fragilis (Hartwig, 1898) & & $2-2$ & & PD \\
\hline Fabaeformiscandona balatonica (Daday, 1894) & & $2-3$ & & $\mathrm{PD}, \mathrm{SL}$ \\
\hline Fabaeformiscandona wegelini (Petkovski, 1962) & & $2-2$ & & LA, ST \\
\hline \multicolumn{5}{|l|}{ Genus Schellencandona Meisch, 1996} \\
\hline Schellencandona sp. & Schsp & $1-2$ & & WL \\
\hline \multicolumn{5}{|l|}{ Genus Pseudocandona Kaufmann, 1900} \\
\hline Pseudocandona sp. & & $3-3$ & $\mathrm{X}$ & CA, LA, PD, SP \\
\hline Pseudocandona marchica (Harwig, 1899) & & 4-6 & & KS, PD, PL \\
\hline Pseudocandona sarsi (Hartwig, 1899) & & $2-2$ & & LA, PL \\
\hline Pseudocandona lobipes (Hartwig, 1900) & Plobi & $6-9$ & & $\mathrm{LA}, \mathrm{PB}, \mathrm{PD}, \mathrm{SL}$ \\
\hline Pseudocandona semicognita (Schäfer, 1934) & & $1-1$ & & ST \\
\hline Pseudocandona gr. compressa & & $2-4$ & & KS, PD \\
\hline Pseudocandona cf. insculpta & & $1-1$ & & PD \\
\hline Pseudocandona compressa (Koch, 1838) & Pcomp & $4-7$ & & PB, PD, PL \\
\hline Pseudocandona cf. sucki & & $1-1$ & & $\mathrm{~PB}$ \\
\hline Pseudocandona pratensis (Hartwig, 1901) & Pprat & $3-3$ & & LA, PB, PD \\
\hline Pseudocandona albicans (Brady, 1864) & & $5-5$ & $\mathrm{X}$ & PD, PL, SP, ST \\
\hline Pseudocandona $\mathrm{cf}$. albicans & & $1-1$ & & ST \\
\hline \multicolumn{5}{|l|}{ Genus Cryptocandona Kaufmann, 1900} \\
\hline Cryptocandona vavrai Kaufmann, 1900 & Cvavr & $4-7$ & & $\mathrm{~PB}, \mathrm{ST}$ \\
\hline \multicolumn{5}{|l|}{ Genus Mixtacandona Sywula, 1970} \\
\hline Mixtacandona laisi (Klie, 1938) & & & $\mathrm{X}$ & SP \\
\hline \multicolumn{5}{|l|}{ Genus Candonopsis Vávra, 1891} \\
\hline Candonopsis kingsleii (Brady \& Robertson, 1870) & & $5-5$ & $\mathrm{X}$ & KS, SL, PD \\
\hline Candonopsis scourfieldi Brady, 1910 & Cscou & $9-11$ & & LA, PB, PD, PL, ST \\
\hline \multicolumn{5}{|l|}{ Subfamily Cyclocypridinae Kaufmann, 1900} \\
\hline \multicolumn{5}{|l|}{ Genus Cypria Zenker, 1854} \\
\hline Cypria ophthalmica (Jurine, 1820) & Copht & $79-133$ & $\mathrm{X}$ & $\begin{array}{l}\text { CH, KS, LA, MO, PB, PD, } \\
\text { PL, RI, SL, SP, ST, WD }\end{array}$ \\
\hline Cypria cavernae Wagenleitner, 1990 & & & $\mathrm{X}$ & CA, WL \\
\hline \multicolumn{5}{|l|}{ Genus Physocypria Vávra, 1897} \\
\hline Physocypria kraepelini G.W. Müller, 1903 & Pkrae & $3-4$ & & $\mathrm{CH}, \mathrm{LA}$ \\
\hline Genus Cyclocypris Brady \& Norman, 1889 & & & & \\
\hline Cyclocypris globosa (Sars, 1863) & & $1-1$ & & PB \\
\hline Cyclocypris laevis (O. F. Müller, 1776) & Claev & $39-49$ & & $\begin{array}{l}\text { CH, IA, KS, LA, MO, PB, } \\
\text { PD, PL, SP, ST, SL, WD }\end{array}$ \\
\hline Cyclocypris ovum (Jurine, 1820) & Covum & $53-86$ & & $\begin{array}{c}\mathrm{CA}, \mathrm{CH}, \mathrm{LA}, \mathrm{MO}, \mathrm{PB}, \mathrm{PD}, \\
\text { PL, SP, ST, WD }\end{array}$ \\
\hline Cyclocypris mediosetosa Meisch, 1987 & & $2-2$ & & SP \\
\hline
\end{tabular}

(continued) 
Tab. 1. Continuation.

\begin{tabular}{|c|c|c|c|c|}
\hline & A & $\mathrm{B}$ & $\mathrm{C}$ & $\mathrm{D}$ \\
\hline \multicolumn{5}{|l|}{ Family Ilyocyprididae Kaufmann, 1900} \\
\hline \multicolumn{5}{|l|}{ Subfamily Ilyocypridinae Kaufmann, 1900} \\
\hline \multicolumn{5}{|l|}{ Genus Ilyocypris Brady \& Norman, 1889} \\
\hline Ilyocypris sp. & & $3-3$ & & LA, SP, ST \\
\hline Ilyocypris gibba (Ramdohr, 1808) & & $5-6$ & $\mathrm{X}$ & PD, PL, SP \\
\hline Ilyocypris bradyi Sars, 1890 & Ibrad & $4-5$ & & $\mathrm{~PB}, \mathrm{SP}$ \\
\hline Ilyocypris inermis Kaufmann, 1900 & Iiner & $3-3$ & & LA, PB \\
\hline \multicolumn{5}{|l|}{ Family Notodromadidae Kaufmann, 1900} \\
\hline \multicolumn{5}{|l|}{ Subfamily Notodromadinae, Kaufmann, 1900} \\
\hline \multicolumn{5}{|l|}{ Genus Notodromas Lilljeborg, 1853} \\
\hline Notodromas sp. & & $2-2$ & & LA, PD \\
\hline Notodromas monacha (O.F. Müller, 1776) & Nmona & $3-3$ & & $\mathrm{PD}, \mathrm{SP}$ \\
\hline Notodromas persica Gurney, 1921 & Npers & $20-28$ & $\mathrm{X}$ & $\mathrm{CH}, \mathrm{LA}, \mathrm{PB}, \mathrm{PD}, \mathrm{PL}, \mathrm{SP}$ \\
\hline \multicolumn{5}{|l|}{ Family Cyprididae Baird, 1845} \\
\hline \multicolumn{5}{|l|}{ Subfamily Eucypridinae Bronsthein, 1947} \\
\hline \multicolumn{5}{|l|}{ Genus Eucypris Vávra, 1891} \\
\hline Eucypris virens (Jurine, 1820) & & $3-4$ & $\mathrm{X}$ & ID, PD, PL, WD \\
\hline Eucypris pigra (Fischer, 1851) & Epigr & $2-3$ & & $\mathrm{~PB}, \mathrm{SP}$ \\
\hline \multicolumn{5}{|l|}{ Genus Prionocypris Brady \& Norman, 1896} \\
\hline Prionocypris zenkeri (Chyzer \& Toth, 1858) & & $16-16$ & & CH, LA, RI, SL, SP, ST, WD \\
\hline \multicolumn{5}{|l|}{ Subfamily Cypricercinae McKenzie, 1971} \\
\hline \multicolumn{5}{|l|}{ Genus Bradleystrandesia Broodbakker, 1983} \\
\hline Bradleystrandesia fuscata (Jurine, 1820) & & $1-1$ & $\mathrm{X}$ & ST, PD \\
\hline Bradleystrandesia reticulata (Zaddach, 1844) & & $1-1$ & & WD \\
\hline \multicolumn{5}{|l|}{ Subfamily Herpetocypridinae Kaufmann, 1900} \\
\hline \multicolumn{5}{|l|}{ Genus Herpetocypris Brady \& Norman, 1889} \\
\hline Herpetocypris sp. & Hersp & $4-4$ & & $\mathrm{~PB}, \mathrm{ST}$ \\
\hline Herpetocypris reptans (Baird, 1835) & Herre & $19-20$ & & CH, ID, LA, PB, RI, SP, ST \\
\hline Herpetocypris brevicaudata Kaufmann, 1900 & & $6-6$ & & $\mathrm{CH}, \mathrm{FO}, \mathrm{ID}, \mathrm{RI}, \mathrm{SL}, \mathrm{SP}$ \\
\hline Herpetocypris chevreuxi (Sars, 1896) & & & $\mathrm{X}$ & PD, PL \\
\hline \multicolumn{5}{|l|}{ Genus Psychrodromus Danielopol \& McKenzie, 1977} \\
\hline Psychrodromus sp. & & $4-4$ & & LA, SP \\
\hline Psychrodromus fontinalis (Wolf, 1920) & & $3-4$ & & SP, ST \\
\hline Psychrodromus betharrami Baltanás et al. 1993 & & & $\mathrm{X}$ & SP \\
\hline Psychrodromus cf. betharrami & & $2-2$ & $\mathrm{X}$ & RI, ST \\
\hline Subfamily Cyprinotinae Bronshtein, 1947 & & & & \\
\hline Genus Heterocypris Claus, 1892 & & & & \\
\hline Heterocypris sp. & & $1-1$ & & ST \\
\hline Heterocypris incongruens (Ramdohr, 1808) & & $15-18$ & $\mathrm{X}$ & $\mathrm{CH}, \mathrm{PD}, \mathrm{PL}, \mathrm{SL}, \mathrm{SP}, \mathrm{ST}, \mathrm{TR}$ \\
\hline Heterocypris salina (Brady, 1868) & & $1-2$ & $\mathrm{X}$ & PD, WD \\
\hline Heterocypris reptans (Kaufmann, 1900) & & $5-5$ & & FO, RI, ST \\
\hline Subfamily Dolerocypridinae Triebel, 1961 & & & & \\
\hline Genus Dolerocypris Kaufmann, 1900 & & & & \\
\hline Dolerocypris sinensis (Sars, 1903) & & $2-3$ & & $\mathrm{PD}, \mathrm{ST}$ \\
\hline Subfamily Scottiinae Bronshtein, 1947 & & & & \\
\hline Genus Scottia Brady \& Norman, 1889 & & & & \\
\hline Scottia pseudobrowniana Kempf, 1971 & Sspeu & $8-11$ & & $\mathrm{~PB}, \mathrm{SP}, \mathrm{ST}$ \\
\hline Subfamily Cypridopsinae Kaufmann, 1900 & & & & \\
\hline Genus Cypridopsis Brady, 1867 & & & & \\
\hline Cypridopsis vidua (O. F. Müller, 1776) & Cvidu & $29-40$ & $\mathrm{X}$ & $\begin{array}{c}\mathrm{CH}, \mathrm{IA}, \mathrm{ID}, \mathrm{KS}, \mathrm{LA}, \mathrm{PB}, \mathrm{PD}, \\
\text { PL, ST, WD }\end{array}$ \\
\hline Cypridopsis cf. hartwigi & & $1-1$ & & WD \\
\hline Cypridopsis elongata (Kaufmann, 1900) & & $4-6$ & $\mathrm{X}$ & LA, PB, PD, PL \\
\hline Genus Cavernocypris Hartmann, 1964 & & & & \\
\hline Cavernocypris subterranea (Wolf, 1920) & & $2-2$ & & $\mathrm{~PB}, \mathrm{SP}$ \\
\hline Genus Potamocypris Brady, 1870 & & & & \\
\hline Potamocypris sp. & & $1-1$ & & LA \\
\hline Potamocypris fulva (Brady, 1868) & & $1-1$ & & $\mathrm{SP}, \mathrm{ST}$ \\
\hline Potocypris cf. zschokkei & Pcfzs & $1-3$ & $\mathrm{X}$ & SP \\
\hline Potamocypris fallax Fox, 1967 & Pfall & $3-4$ & & SP, ST \\
\hline Potamocypris similis G.W. Müller, 1912 & & $1-2$ & & LA \\
\hline Potamocypris villosa (Jurine, 1820) & & $1-1$ & & PD \\
\hline Potamocypris arcuata (Sars, 1903) & & & $\mathrm{X}$ & $\mathrm{PD}, \mathrm{PL}$ \\
\hline
\end{tabular}

(continued) 
Tab. 1. Continuation.

\begin{tabular}{|c|c|c|c|c|}
\hline & A & B & $\mathrm{C}$ & $\mathrm{D}$ \\
\hline \multicolumn{5}{|l|}{ Superfamily Cytheroidea Baird, 1850} \\
\hline \multicolumn{5}{|l|}{ Family Limnocytheridae Klie, 1938} \\
\hline \multicolumn{5}{|l|}{ Subfamily Limnocytherinae Klie, 1938} \\
\hline \multicolumn{5}{|l|}{ Genus Limnocythere s. str. Brady, 1867} \\
\hline Limnocythere inopinata (Baird, 1843) & & $1-1$ & & LA \\
\hline \multicolumn{5}{|l|}{ Subfamily Timiriaseviinae Mandelstam, 1960} \\
\hline \multicolumn{5}{|l|}{ Genus Metacypris Brady \& Robertson, 1870} \\
\hline Metacypris cordata Brady \& Robertson, 1870 & Mcord & $6-9$ & & PB, PL, ST \\
\hline \multicolumn{5}{|l|}{ Genus Cyprideis Jones, 1857} \\
\hline Cyprideis torosa (Jones, 1850) & Ctoro & $6-9$ & $\mathrm{X}$ & $\mathrm{PD}, \mathrm{SL}, \mathrm{WD}$ \\
\hline \multicolumn{5}{|l|}{ Family Leptocytheridae Sars, 1925} \\
\hline \multicolumn{5}{|l|}{ Genus Leptocythere Sars, 1925} \\
\hline Leptocythere sp. & & $1-1$ & & SP \\
\hline \multicolumn{5}{|l|}{ Family Xestoleberididae, Sars, 1866} \\
\hline \multicolumn{5}{|l|}{ Genus Xestoleberis, Sars, 1866} \\
\hline Xestoleberis sp. & Xessp & $2-2$ & & WD \\
\hline \multicolumn{5}{|l|}{ Family Enthocytheridae Hoff, 1942} \\
\hline \multicolumn{5}{|l|}{ Subfamily Spheromicolinae Hart, 1962} \\
\hline \multicolumn{5}{|l|}{ Genus Sphaeromicola Paris, 1916} \\
\hline Sphaeromicola stammeri Klie, 1932 & & & $\mathrm{X}$ & CA \\
\hline
\end{tabular}

Fifteen taxa were only recovered from one sample: C. angulata, Pseudocandona semicognita, $P$. cf. sucki, $P$. cf. albicans, $P$. cf. insculpta, C. globosa, Bradleystrandesia reticulata, B. fuscata, Heterocypris sp., C. cf. hartwigi, Potamocypris sp., P. fulva, P. villosa, Limnocythere inopinata and Leptocythere sp. The average number of taxa per samples (excluding immature specimens, isolated valves and empty carapaces) was 2.09; 218 samples contained one or two ostracod species. The highest ostracod diversity (7 taxa) was recorded in three samples respectively collected from a stream, a spring and a pool.

The study led to the recognition of 39 species not yet reported for Friuli Venezia Giulia (Tab. 1); the records of Microdarwinula zimmeri, Penthesilenula brasiliensis, Fabaeformiscandona wegelini, P. semicognita, Candonopsis scourfieldi, and Cyclocypris mediosetosa are also new for the Italian ostracod fauna (Ghetti \& McKenzie 1981; Meisch 2000). Cyclocypris globosa is the second record for Italy, the first one for peat bogs in Veneto (NE Italy) (Pieri 2007). Also Metacypris cordata is only known for one other Italian locality (Lake of Bolsena, Central Italy) (Meisch 2000).

Six species reported in previous investigations on Friuli Venezia Giulia ostracods (Mixtacandona laisi, Cypria cavernae, Psychrodromus betharrami, Herpetocypris chevreuxi, Potamocypris arcuata and Sphaeromicola stammeri) were not found in the collected samples (Tab. 1).

Among the taxa identified in the present study, Candonopsis kingsleii, Ilyocypris bradyi, I. inermis, $H$. reptans, Cyprideis torosa and Xestoleberis sp. showed a peculiar geographic distribution, being exclusively recorded in the southern part of the Friuli Venezia Giulia region and at altitudes below $240 \mathrm{~m}$ a.s.l. In particular, C. torosa and Xestoleberis sp. were mostly found in brackish habitats connected to marine areas.
On the other hand, Cryptocandona vavrai, Cyclocypris mediosetosa, Eucypris pigra, Psychrodromus fontinalis and Cavernocypris subterranea, characteristic of spring habitats, were found only in the northern part of the region. The occurrence of these taxa was restricted to samples collected in springs and peat bogs located at altitudes higher than $840 \mathrm{~m}$ a.s.l. Fabaeformiscandona fragilis, $P$. marchica, Ilyocypris gibba and E. virens were only found in the province of Gorizia, in the south east part of the region, mostly in lowland ponds and wetlands.

In most of the samples (70 out of 111), conductivity values were below $500 \mu \mathrm{S} \mathrm{cm}^{-1}$. The highest conductivity values (up to $20 \mathrm{mS} \mathrm{cm}^{-1}$ ) were recorded in brackish sites located near the sea. Temperature was extremely variable among sites and sampling periods, showing values between 5.2 and $32.5^{\circ} \mathrm{C}$. Dissolved oxygen concentrations were mostly below $10 \mathrm{mg} \mathrm{L}^{-1}$, and $\mathrm{pH}$ values were generally between 7 and 8 , with extremes of 4.34 and 9.02 , respectively measured in a peat bog and in a pond.

Figure 4 shows the range of selected environmental variables for the 5 most frequent ostracod species found in the study area. Cypria ophthalmica and Cyclocypris ovum have a wide tolerance towards the considered hydrochemical variables. On the other hand, Notodromas persica, C. laevis and Cypridopsis vidua were found at $\mathrm{pH}$ values higher than 6.9 , and C. vidua seems to prefer habitats with conductivity values below 600 $\mu \mathrm{S} \mathrm{cm}^{-1}$. Cypridopsis vidua and N. persica are clearly present at lower altitudes and higher water temperatures than the other common species; $N$. persica can be also found in hypoxic or anoxic conditions.

The occurrence of some taxa was clearly restricted to particular habitat types. For example, the congeneric Psychrodromus fontinalis and $P$. cf. betharrami were mainly found in springs; Cavernocypris subterranea and Cryptocandona vavrai were only collected in peat bogs located at high altitude. 

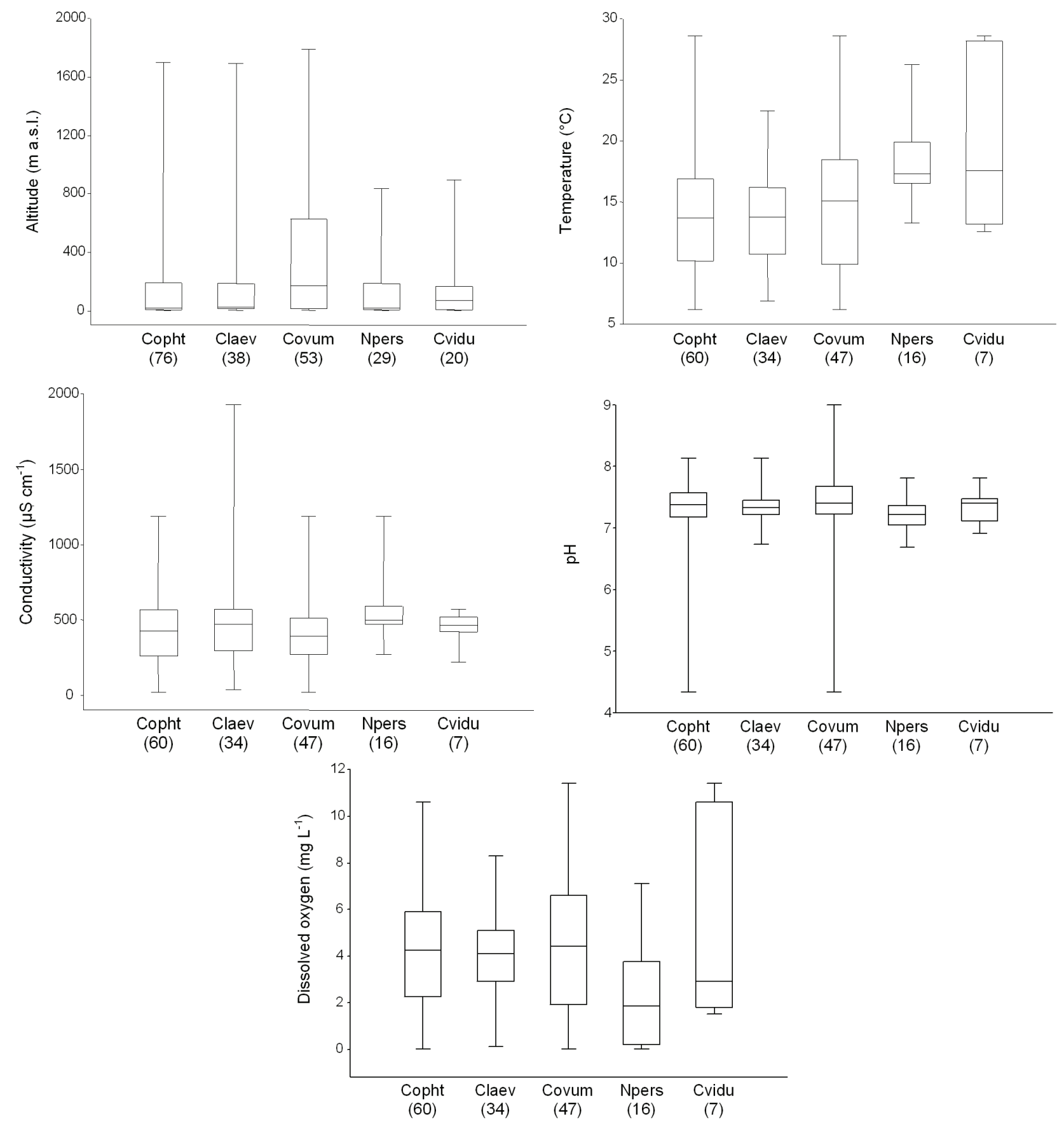

Fig. 4. Box plots showing the range of selected environmental variables for the most frequent ostracod species (Copht: Cypria ophthalmica; Claev: Cyclocypris laevis; Covum: Cyclocypris ovum; Npers: Notodromas persica; Cvidu: Cypridopsis vidua) found in the study area. For each variable, the $25-75$ percent quartiles are drawn using a box. The range of values is shown with vertical lines ("whiskers"), the median with a horizontal line inside the box. Figures in brackets refer to the number of analysed samples.

The first two axes of CCA (Fig. 5) account for $84.3 \%(61.0 \%$ the first axis and $23.3 \%$ the second axis) of the cumulative percentage variance of the speciesenvironment relation. The species-environment correlations are 0.796 for axis 1 and 0.532 for axis 2. The Monte Carlo permutation test shows that all the canonical axes are significant $(P<0.001)$. Conductivity (permutation test: $F=2.14, P=0.004$ ) and altitude (per- mutation test: $F=4.92, P=0.001$ ) have the strongest correlations to the first axis, while temperature has the strongest correlation to the second axis (permutation test: $F=1.95, P=0.006)$. Dissolved oxygen and $\mathrm{pH}$ were not included in this analysis, because these variables were not significant. In the ordination diagram, the most common ostracod taxa are grouped around the origin of the axes, meaning that their occurrence is weakly 


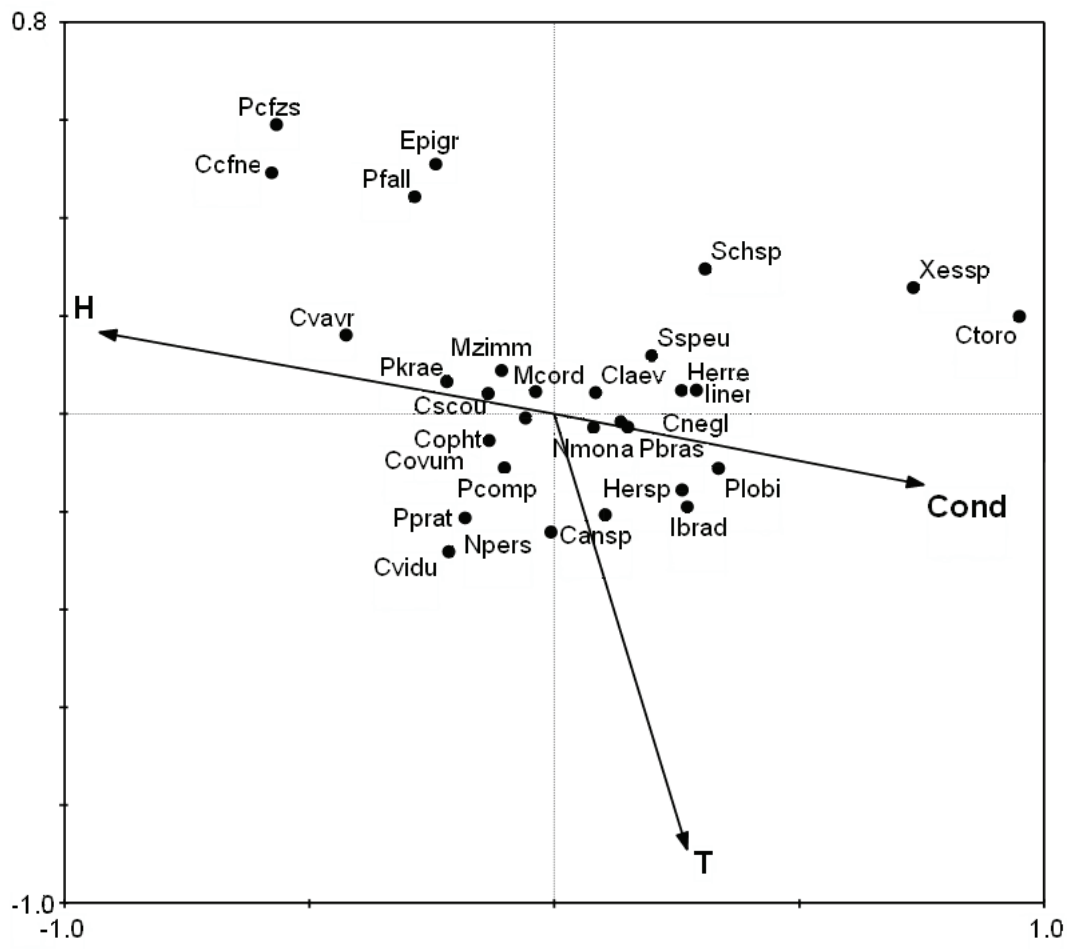

Fig. 5. CCA ordination of ostracod taxa and environmental variables (H: altitude; Cond: conductivity; T: temperature) on the space defined by the first two canonical axes. Taxa are labelled as in table 1 .

related to specific environmental gradients. The brackish water taxa Xestoleberis sp. and Cyprideis torosa are clearly separated from a cluster of species (Candona cf. neglecta, Eucypris pigra, Potamocypris cf. zschokkei, and Potamocypris fallax) typical of habitats located at high elevations and characterized by low conductivity values.

\section{DISCUSSION AND CONCLUSIONS}

The present work greatly increases the information available on freshwater ostracods from Friuli Venezia Giulia and, in general, from Italy. In fact, Friuli Venezia Giulia is so far the region with the highest ostracod species diversity in Italy (Pieri 2007; Pieri et al. 2006, 2007). Moreover, if one considers that in Italy the number of valid species of non-marine ostracods is roughly 150 (not including taxa at subspecific rank) (Pieri 2007), Friuli Venezia Giulia accounts for more than one third of the entire country's ostracod specific diversity even though it covers only $2.6 \%$ of the total national area. This result depends on the considerable sampling effort and on the variety of types of aquatic habitats that are present in the study area.

Most of the species identified in this survey have a wide geographic distribution or are cosmopolitan, and are known for their broad ecological tolerance. In other cases, the distribution of ostracod taxa appeared to be closely associated to specific habitat types.

CCA is used in the present work to assess the relationships between species occurrence and environ- mental factors. This robust, multivariate technique was frequently applied to the study of non-marine ostracod assemblages (e.g., Rossetti et al. 2004; Mezquita et al. 2005; Külköylüoğlu \& Yilmaz 2006; Viehberg 2006; Yilmaz \& Külköylüoğlu 2006). Our analysis shows a high cumulative variance of species-environment relation captured by the first two axes of CCA, expressing the amount of variance explained by the axes as a fraction of the total variance. In the literature, a wide range of figures can be found for the variance accounted by the first two canonical axes, and values comparable to or even higher than those of our analysis are not uncommon. Such large variability in the resulting scores may depend, among other factors, on the size and properties of the data sets (i.e., number of species and variables considered, frequency of species absences in the input matrix, amplitude of environmental gradients, etc.). The high variance explained by our analysis can be interpreted considering that only significant environmental variables were entered into the model, while taxa with a single record were excluded. But it also clearly indicates that, at the considered regional scale, the distribution of freshwater ostracods is strongly related to the altitudinal gradient and physico-chemical characteristics of the waters, namely temperature and conductivity.

Previous studies on the non-marine ostracods of Friuli Venezia Giulia were primarily focused on the ground waters of the karst areas. For this reason, a sig- 
nificant proportion of the ostracod fauna of this region was represented by stygobiotic species (Tab. 1). Among these, Cypria cavernae and Sphaeromicola stammeri are of particular interest. Cypria cavernae is the only blind and unpigmented species of the genus; it was found only in the in the saturated groundwaters of the karst area around Trieste (Wagenleitner 1990). Sphaeromicola stammeri lives as a commensal on stygobiotic isopods of the genus Monolistra (Stoch 1993). These species were not collected during the present survey, which did not take into account karstic groundwaters.

Some records of ostracod taxa from Friuli Venezia Giulia are of considerable interest from a biogeographic perspective. Microdarwinula zimmeri is a small ostracod species $(<0.4 \mathrm{~mm})$ preferring interstitial waters. In Europe, Recent populations were only found in Romania and Southern France; other Pleistocene records are from Germany and Central Italy (Devoto 1965; Danielopol 1968; Martens et al. 1997; Rossetti \& Martens 1998). Penthesilenula brasiliensis is known from all continents, with the exception of North America and Antarctica. The species has been reported from rivers and streamlets, interstitial habitats, mosses, water inside bromeliad pouches and leaf litter of rain forests; Recent European populations are known for the British Isles (including Ireland) and Southern France (Rossetti \& Martens 1998). Together with the cosmopolitan Darwinula stevensoni, these new records bring the number of species of the family Darwinulidae reported from Italy to three.

The genus Schellencandona is new for Italy and it is known from France, Belgium, Austria, Germany and Southern Japan (Meisch 2000; Smith \& Kamiya 2006). All the species of the genus are stygobiotic; their small size $(0.6 \mathrm{~mm})$ and the absence of the pigmented eyes are adaptations to the hypogean life (Meisch 1996). In this study only two specimens were found in two different samples collected from a phreatic well.

The species belonging to the genus Xestoleberis are generally marine, but some species were also found in brackish and freshwater habitats (McKenzie 1977). The examined material from Friuli Venezia Giulia consisted of two specimens collected among reed stands in a slow-flowing section of the terminal reach of a small river (Cavana) feed by resurgences close to the sea.

Cyclocypris mediosetosa was so far only known from a streamlet flowing from a spring in Southern France; this species is closely related to C. ovum, from which it differs in the length of the natatory setae of the second antenna and the presence of a transverse band with shallow pits on the valves (Meisch 2000). Our specimens were collected in rheocrenic springs associated to peat bog habitats.

The records of Fabaeformiscandona wegelini and Pseudocandona semicognita considerably extend the distribution range of these poorly known ostracod species [see Meisch (2000) and references therein].
The only specimen of Leptocythere sp., collected in a spring of the Southern part of the study area, shows affinities with $L$. fluviatils, an endemic species known from a single locality of the Krka River at Novo Mesto (SE Slovenia) (Klie 1939). The collection of new material will hopefully allow confirmation of its specific status.

A further comparison of the ostracod fauna of Friuli Venezia Giulia with that of Slovenia is of some interest, as the two geographic areas are adjacent and largely share common landscape and geological features. The ostracod checklist of Slovenia includes 47 taxa arranged in 22 genera (Griffiths \& Brancelj 1996). Two genera reported for Slovenia, Cytherissa and Nannocandona, both represented by one species, were not found in the present study. Although still preliminary, the data from Slovenia also confirm the presence of a "biodiversity hotspot" for the ostracod fauna in the Alpine-Adriatic region, and in particular the high incidence of strict endemics with limited geographic distribution. This favourable circumstance, however, raises some issues about the conservation of the aquatic habitats which host such a natural patrimony of animal diversity. In fact, most of the water bodies included in this study are extremely small and exposed to potential impacts at both local and global scales.

\section{ACKNOWLEDGEMENTS}

The authors would like to thank Renate MatzkeKarasz (Ludwig-Maximilian University, Munich), Claude Meisch (Musée national d'histoire naturelle de Luxembourg), Dan Danielopol (University of Graz) and Ricardo L. Pinto (University of São Paulo) for their help during this study. The comments and criticism of two referees contributed to improve the scientific quality of the paper. Julien Cillis (R.B.I.N.Sc., Brussels) offered technical assistance with the scanning electron micrographs. The field work was mainly carried out by one of the authors (FS), partly thanks to funds of the Friuli Venezia Giulia regional administration; Gianfranco Tomasin offered technical help during most of the field surveys. Ostracods were partly identified during a visit of VP to KM founded by the EU Project SYNTHESYS. KM and GR acknowledge the support of the EU Project SEXASEX (MRTN-CT-2004-512492).

\section{REFERENCES}

Baltanás, A., D.L. Danielopol, J.R. Rocha \& P. Marmonier. 1993. Psychrodromus betharrami n. sp. (Crustacea, Ostracoda): Morphology, Ecology and Biogeography. Zool. Anz., 231: 39-57.

Bou, C. 1974. Les méthodes de récolte dans les eaux souterraines interstitielles. Annls. Spéléol., 29: 611-619.

Bou, C. \& R. Rouch. 1967. Un nouveau champ de recherches sur la faune aquatique souterraine. C. R. Hebd. Séances Acad. Sci. Ser. III. Sci. Vie, 265: 369-370.

Chappuis, P.A. 1942. Eine neue Methode zur Untersuchung der Grundwasserfauna. Acta Sci. Math. Nat. Univ. Francisco-Josephina Kolozsvar, 6: 1-7. 
Danielopol, D.L. 1968. Microdarwinula n.g. et quelques remarques sur la répartition de la famille Darwinulidae $\mathrm{Br}$. et Norm. (Crustacea, Ostracoda). Annls. Limnol., 4: 153174.

Devoto, G. 1965. Lacustrine Pleistocene in the Lower Liri Valley. Geol. Rom., 6: 291-368.

Ghetti, P.F. \& McKenzie K. 1981. Ostracodi (Crustacea: Ostracoda). Guide per il riconoscimento delle specie animali delle acque interne italiane. Consiglio Nazionale delle Ricerche, Roma.

González Mozo, M.E., K. Martens \& A. Baltanás. 1996. A taxonomic revision of European Herpetocypris Brady and Norman, 1889 (Crustacea, Ostracoda). Bull. K. Belg. Inst. Natuurw. Biol., 66: 93-132.

Griffiths, H.I. \& A. Brancelj. 1996. Preliminary list of freshwater Ostracoda (Crustacea) from Slovenia. Annals for Istrian and Mediterranean Studies, 9: 201-210.

Klie, W. 1939. Studien über Ostracoden aus dem Ohridsee: II. Limnocytherinae und Cytherinae. Arch. Hydrobiol., 38: 631-646.

Külköylüoğlu, O. \& F. Yilmaz. 2006. Ecological requirements of Ostracoda (Crustacea) in three types of springs in Turkey. Limnologica, 36: 172-180.

Martens, K. 1992. A reassessment of Paralimnocythere Carbonnel, 1965 (Crustacea, Ostracoda, Limnocytherinae), with a description of a new genus and two new species. Bull. K. Belg. Inst. Natuurw. Biol., 62: 125-158

Martens, K., G. Rossetti \& R. Fuhrmann. 1997. Pleistocene and Recent species of the family Darwinulidae Brady \& Norman, 1889 (Crustacea, Ostracoda) in Europe. Hydrobiologia, 357: 99-116.

Martens, K., I. Schön, C. Meisch, \& D.J. Horne. 2008. Global diversity of ostracods (Ostracoda, Crustacea) in freshwater. Hydrobiologia, 595: 185-193.

Masi, L. 1905. Nota sugli Ostracodi viventi nei dintorni di Roma ed osservazioni sulla classificazione delle Cypridae. Boll. Soc. Zool. Ital., 7/8: 191-204.

Masi, L. 1909. Descrizione di alcune Cypridae italiane. Arch. Zool. Ital., 3 (4): 347-407.

McKenzie, K.G. 1977. Crustacea: Ostracoda. In: La faune terrestre de l'île de Sainte-Hélène. Quatriéme partie. Annalen, Koninklijk Museum voor Midden-Afrik - Zoologische wetenschappen, 220: 445-451.

Meisch, C. 1984. Revision of the Recent Western Europe species of genus Potamocypris. Part I: Species with short swimming setae on the second antennae. Trav. Sc. Mus. Nat. Hist. Nat. Luxemb., 3: 1-55.

Meisch, C. 1985. Revision of the Recent Western Europe species of genus Potamocypris. Part II: Species with long swimming setae on the second antennae. Trav. Sc. Mus. Nat. Hist. Nat. Luxemb., 6: 1-95.

Meisch, C. 1996. Contribution to the taxonomy of Pseudocandona and four related genera, with the description of Schellencandona nov. gen., a list of the Candoninae genera, and a key to the European genera of the subfamily (Crustacea, Ostracoda). Bull. Soc. Nat. luxemb., 97: 211237.

Meisch, C. 2000. Freshwater Ostracoda of Western and Central Europe. Spektrum Academischer, Heidelberg, Berlin.

Mezquita, F., J.R. Roca, J.M. Reed \& G. Wansard. 2005. Quantifying species-environment relationships in non-marine Ostracoda for ecological and palaeoecological studies: examples using Iberian data. Palaeogeogr. Palaeoclimat. Palaeoecol., 225: 93-117.

Mezzanotte, E. \& B. Sambugar. 2004. Contributo alla conoscenza della fauna delle sorgenti. Memorie del Museo Civico di Storia Naturale di Verona - 2. Serie - Monografie Naturalistiche, 1: 283-292.

Petkovski, T.K. \& D. Keyser. 1992. Leptocythere ostrovskensis sp. n. (Crustacea, Ostracoda, Cytheracea) aus dem See
Vegoritis (Ostrovsko Ezero) in NW Griechenland. Mitt. hamb. zool. Mus. Inst., 89: 227-237.

Pieri, V. 2007. Ricerche su biodiversità, pattern distribuzionali ed ecologia di ostracodi (Crustacea, Ostracoda) non marini Recenti e loro possibile impiego come indicatori di qualità delle acque. $\mathrm{PhD}$ thesis, University of Trieste.

Pieri, V., K. Martens, L. Naselli-Flores, F. Marrone \& G. Rossetti. 2006. Distribution of Recent ostracods in inland waters of Sicily (Southern Italy). J. Limnol., 65: 1-8.

Pieri, V., C. Caserini, S. Gomarasca, K. Martens \& G. Rossetti. 2007. Water quality and diversity of the Recent ostracod fauna in lowland springs from Lombardy (northern Italy). Hydrobiologia, 585: 79-87.

Pinto, R.L., C.E.F. Rocha \& K. Martens. 2005. On the evolution of the genus Microdarwinula Danielopol, 1968 (Ostracoda, Darwinulidae) with the description of a new species from semi-terrestrial habitats in São Paulo State (Brazil). Crustaceana, 78: 975-986.

Rossetti, G. \& K. Martens. 1998. Taxonomic Revision of the Recent and Holocene representatives of the Family Darwinulidae (Crustacea, Ostracoda), with a description of three new genera. Bull. K. Belg. Inst. Natuurw. Biol., 68: $55-110$

Rossetti, G., M. Bartoli \& K. Martens. 2004. Limnological charateristics and recent ostracods (Crustacea, Ostracoda) of freshwater wetlands in the Parco Oglio Sud (Northern Italy). Annls. Limnol., 40: 329-341.

Rossetti, G., V. Pieri \& K. Martens. 2005. Recent ostracods (Crustacea, Ostracoda) found in lowland springs of the provinces of Piacenza and Parma (Northern Italy). Hydrobiologia, 542: 287-296.

Rossetti, G., K. Martens, C. Meisch, S. Tavernelli \& V. Pieri. 2006. Small is beautifull: diversity of freshwater ostracods (Crustacea, Ostracoda) in marginal habitats of the province of Parma (Northern Italy). J. Limnol., 65: 121-131.

Rossi, V., G. Benassi, M. Veneri, C. Bellavere, P. Menozzi \& A. Moroni. 2003. Ostracoda of the italian ricefields thirty years on: new synthesis and hypotesis. J. Limnol., 62: 1-8.

Smith, R.J. \& T. Kamiya. 2006. Six new species of fresh and brackish water ostracods (Crustacea) from Yakushima, Southern Japan. Hydrobiologia, 559: 331-335.

Stoch, F. 1985. Contributo alla conoscenza dei popolamenti ad entomostraci delle acque epigee del Carso triestino (Italia nordorientale). Atti Mus. civ. St. nat. Trieste, 37: 161-182.

Stoch, F. 1992. Prime ricerche faunistiche sulle acque sotterranee nelle aree urbanizzate della Provincia di Trieste. Boll. Soc. Adr. Speleol., Trieste: 62-66.

Stoch, F. 1993. Indagini faunistiche sui crostacei delle acque sotterranee dell'alta Val Torre (Italia nordorientale). Gortania, Atti Mus. Friul. St. Nat., Udine, 14: 167-183.

Stoch, F. 1995. Indagine ecologico-faunistica sui popolamenti a entomostraci di alcuni stagni d'acqua salmastra dell'Isola della Cona (foce del Fiume Isonzo, Italia nordorientale). Gortania, Atti Mus. Friul. St. Nat., Udine, 16: 151-173.

Stoch, F. 1996. La fauna delle acque carsiche sotterranee delle Valli del Torre e del massiccio dei monti La Bernadia. Mem. Ist. It. Spel., s. II, 8: 81-88.

Stoch, F. 1997. La fauna delle acque carsiche sotterranee delle Valli del Natisone. Mem. Ist. It. Spel., s. II, 9: 73-84.

Stoch, F. 2003. Indagini ecologiche e faunistiche sulla meiofauna (Acari e Crostacei) di alcune sorgenti del Parco Naturale delle Prealpi Giulie (Italia nord-orientale). Gortania, Atti Mus. Friul. St. Nat., Udine, 25: 239-250.

Stoch, F. 2004. Prime osservazioni sulla fauna delle acque carsiche sotterranee delle Alpi Carniche. Mem. Ist. It. Spel., s. II, 15: 87-95.

Stoch, F. \& S. Dolce. 1994. Progetto Timavo: risultati delle indagini sulla fauna delle acque sotterranee. Atti Mem. Comm. Grotte "E. Boegan", Trieste, 31: 59-71.

ter Braak, C.J.F. \& P. Šmilauer. 2002. CANOCO Reference Manual and CanoDraw for Windows User's Guide: Soft- 
ware for Canonical Community Ordination (version 4.5). Microcomputer Power, Ithaca.

Viehberg, F.A. 2006. Freshwater ostracod assemblages and their relationship to environmental variables in waters from northeast Germany. Hydrobiologia, 571: 213-224.
Wagenleitner, H. 1990. Morphology and evolution of Cypria cavernae n. sp. (Ostracoda, Crustacea). Bull. Soc. Nat. luxemb., 90: 199-226.

Yilmaz, F. \& O. Külköylüoğlu. 2006. Tolerance, optimum ranges, and ecological requirements of freshwater Ostracoda (Crustacea) in Lake Aladağ (Bolu, Turkey). Ecol. Res., 21: 165-173.

\section{$\begin{array}{llllllll}\text { A } & \text { P } & \text { P } & \text { E } & \text { N } & \text { D } & \text { I } & X\end{array}$}

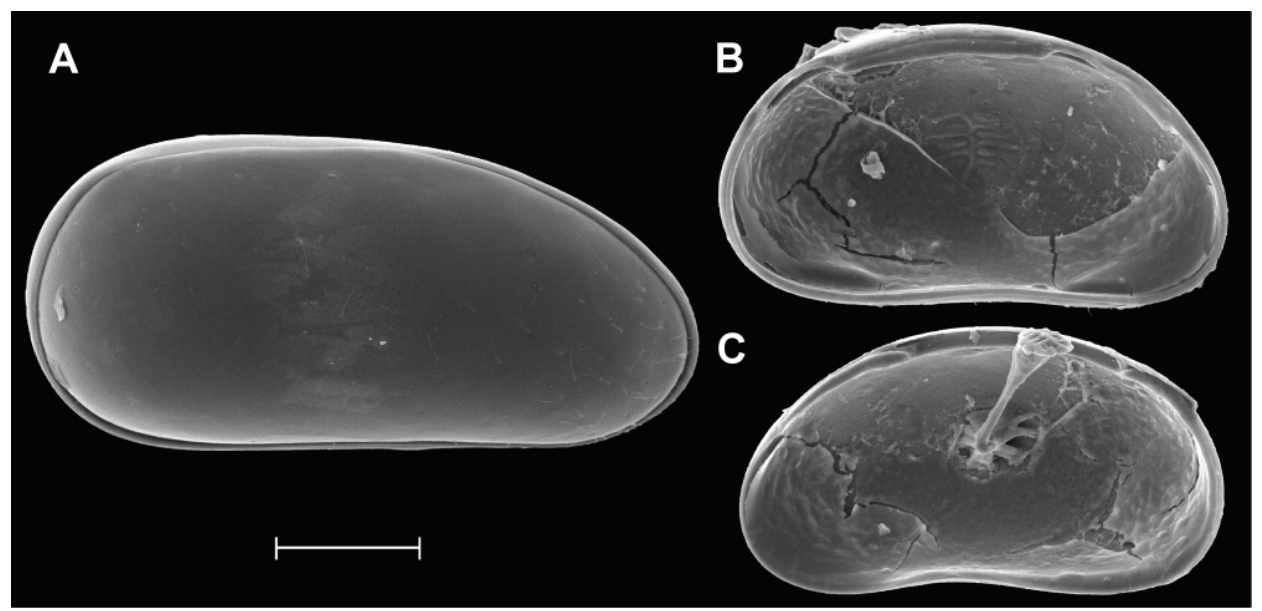

Plate 1. Penthesilenula brasiliensis (A); Microdarwinula zimmeri (B-C). All adult specimens. (A): VP0626, female, Cp, Rlv; (B): VP0534, female, LV, iv; (C): idem, RV, iv. Scale bar: $100 \mu \mathrm{m}$ for A-C.

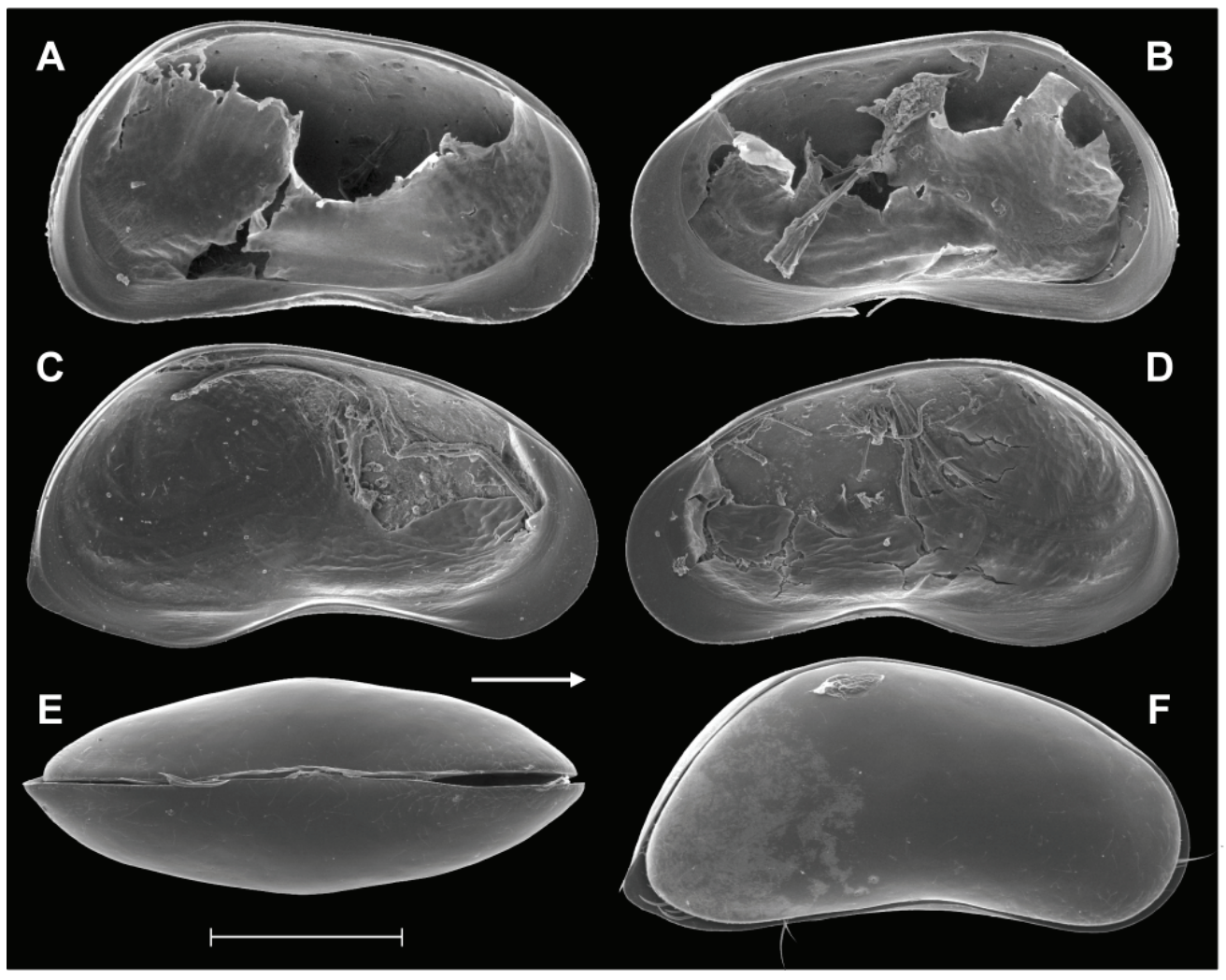

Plate 2. Candona neglecta (A-B); Candona angulata (C-F). All adult specimens. (A): VP0568, female, LV, iv; (B): idem, RV, iv;

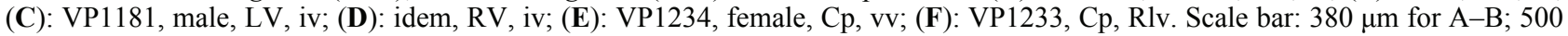
$\mu \mathrm{m}$ for $\mathbf{C}-\mathbf{F}$. 


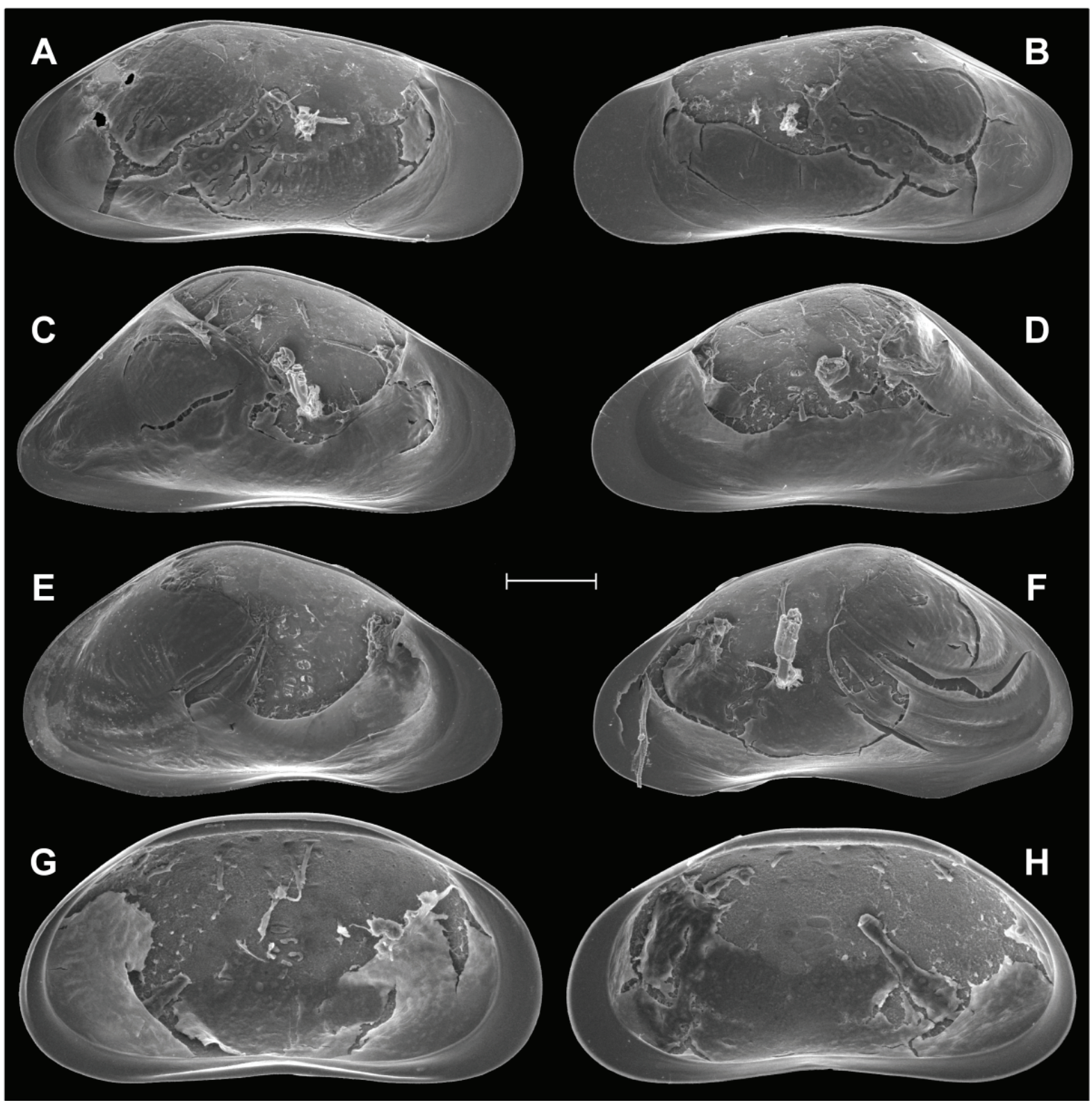

Plate 3. Fabaeformiscandona fragilis (A-B); Fabaeformiscandona balatonica (C-F); Fabaeformiscandona wegelini (G-H). All adult specimens. (A): VP1214, female, LV, iv; (B): idem, RV, iv; (C): VP1176, female, LV, iv; (D): idem, RV, iv; (E): VP1175, male, LV, iv; (F): idem, RV, iv; (G): VP1129, female, LV, iv; (H): idem, RV, iv. Scale bar: $200 \mu \mathrm{m}$ for A-B; $261 \mu \mathrm{m}$ for C-F; 97 $\mu \mathrm{m}$ for $\mathbf{G}-\mathbf{H}$. 


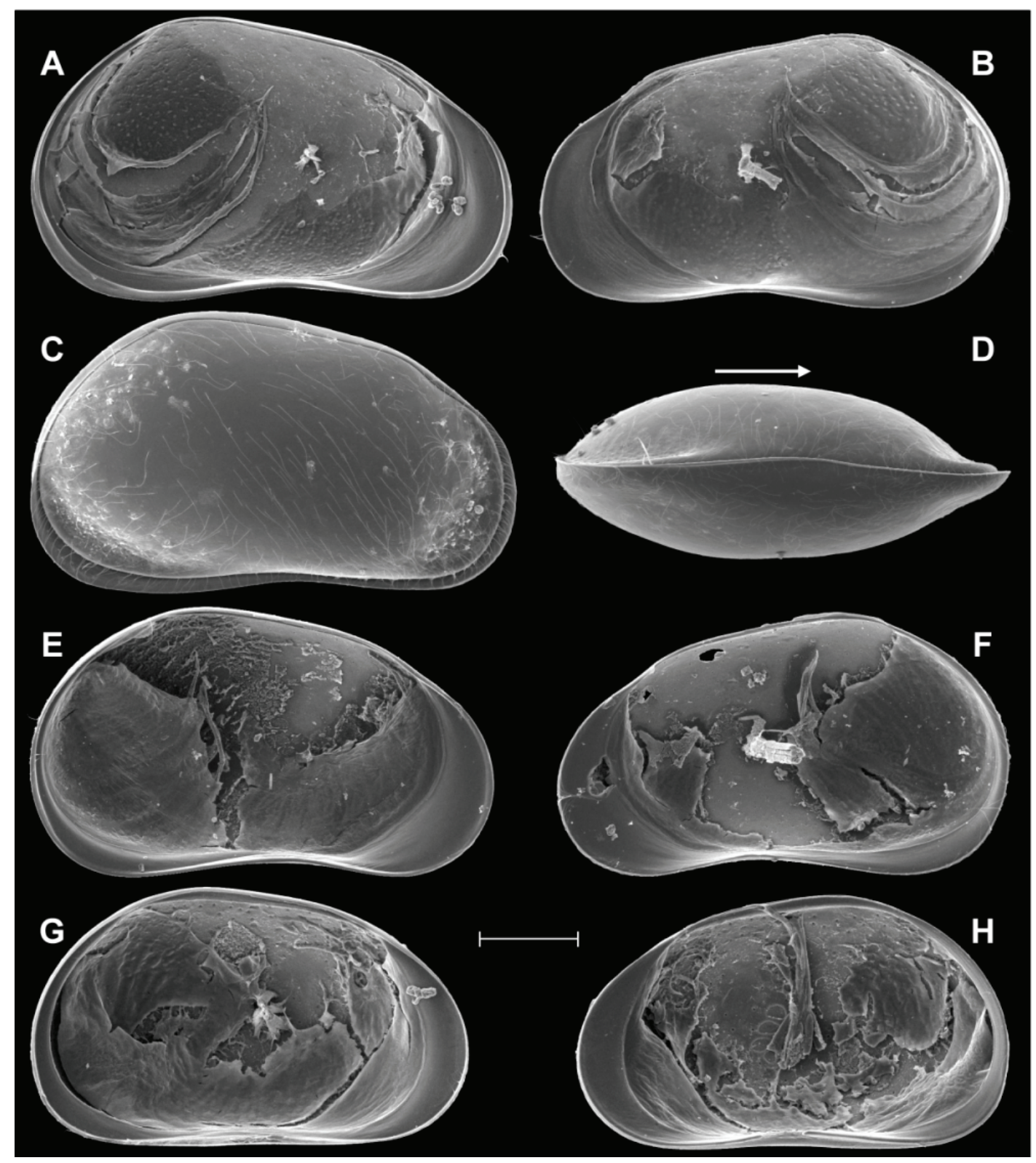

Plate 4. Pseudocandona marchica (A-D); Pseudocandona sarsi (E-F); Pseudocandona lobipes (G-H). All adult specimens. (A): VP1207, male, LV, iv; (B): idem, RV, iv; (C): VP1227, female, Cp, RLv; (D): VP1228, female, Cp, vv; (E): VP1200, male, LV, iv; (F): idem, RV, iv; (G): VP1183, female, LV, iv; (H): idem, RV, iv. Scale bar: $200 \mu \mathrm{m}$ for A-D; $261 \mu \mathrm{m}$ for $\mathbf{E}-\mathbf{F} ; 185 \mu \mathrm{m}$ for $\mathbf{G}-\mathbf{H}$. 


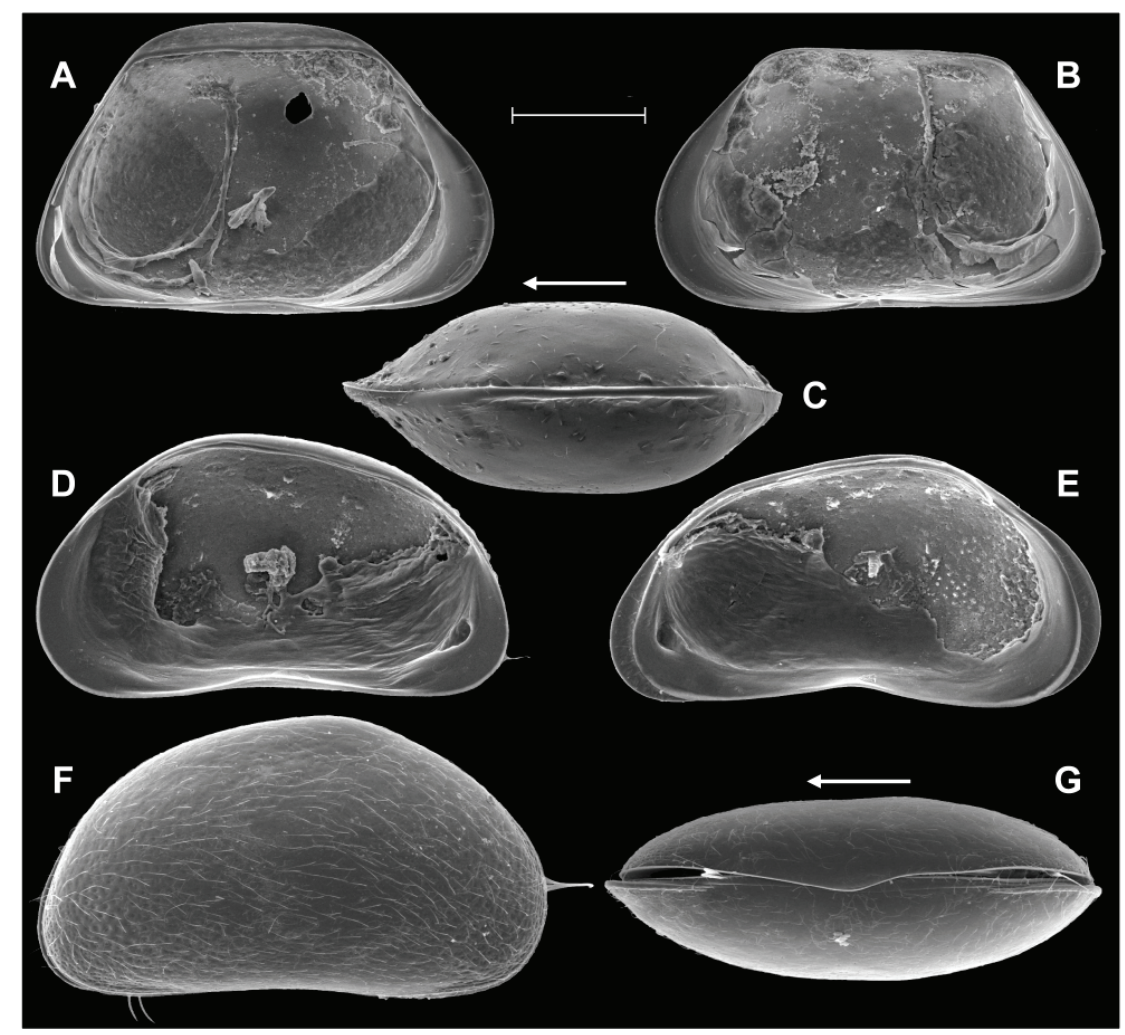

Plate 5. Schellencandona sp. (A-C); Potamocypris fallax (D-G). All adult specimens. (A): VP0602, male, LV, iv; (B): idem, RV, iv; (C): VP0630, female, Cp, vv; (D): VP1088, female, LV, iv; (E): idem, female, RV, iv; (F): VP1226, Cp, Rlv; (G): VP1225, female, Cp, vv. Scale bar: $200 \mu \mathrm{m}$ for A-C; $185 \mu \mathrm{m}$ for D-G..

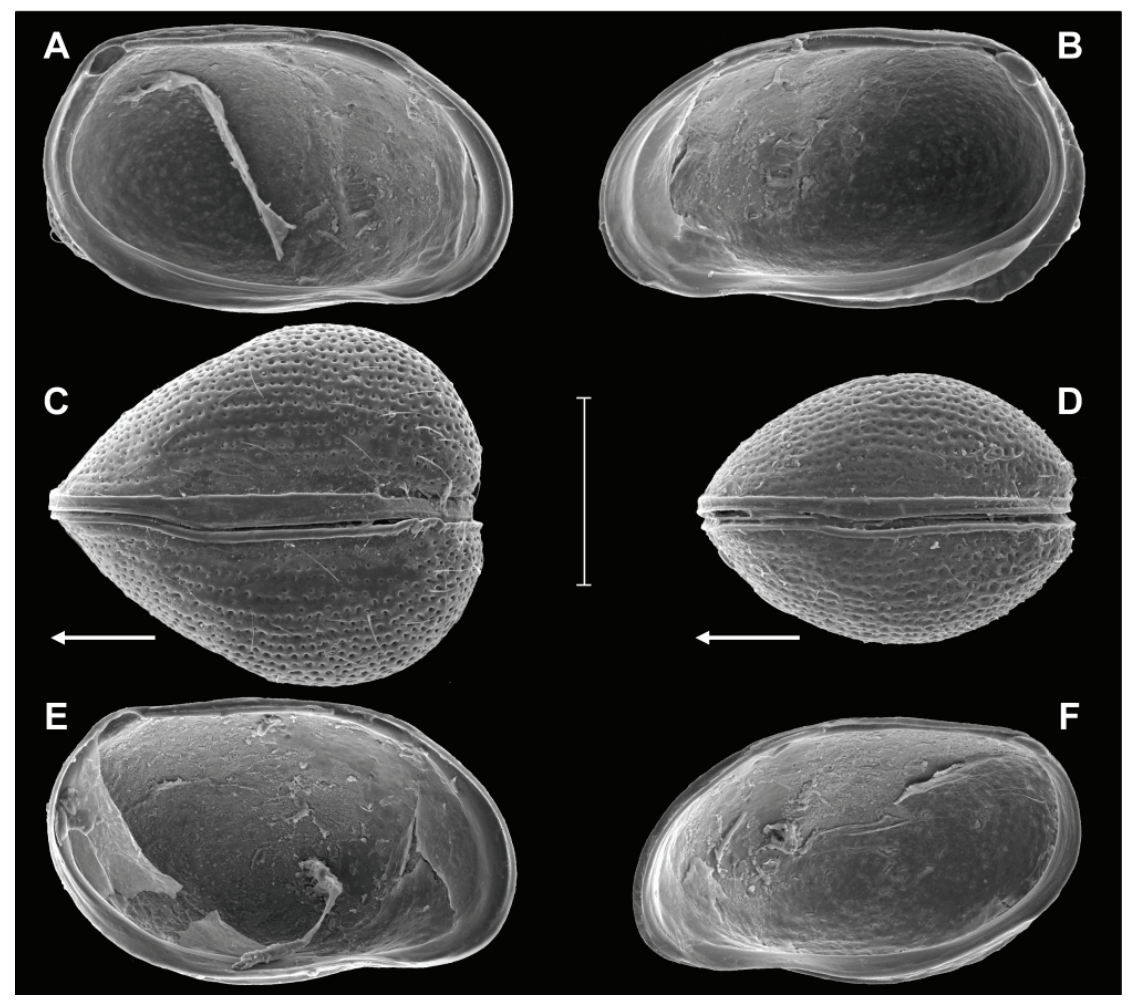

Plate 6. Metacycpris cordata (A-F). All adult specimens. (A): VP0569, female, LV, iv; (B): idem, RV, iv; (C): VP0637, female, Cp, vv; (D): VP0636, male, Cp, vv; (E): VP0570, male, LV, iv; (F): idem, RV, iv. Scale bar: $200 \mu \mathrm{m}$ for A-C; $233 \mu \mathrm{m}$ for D-F. 


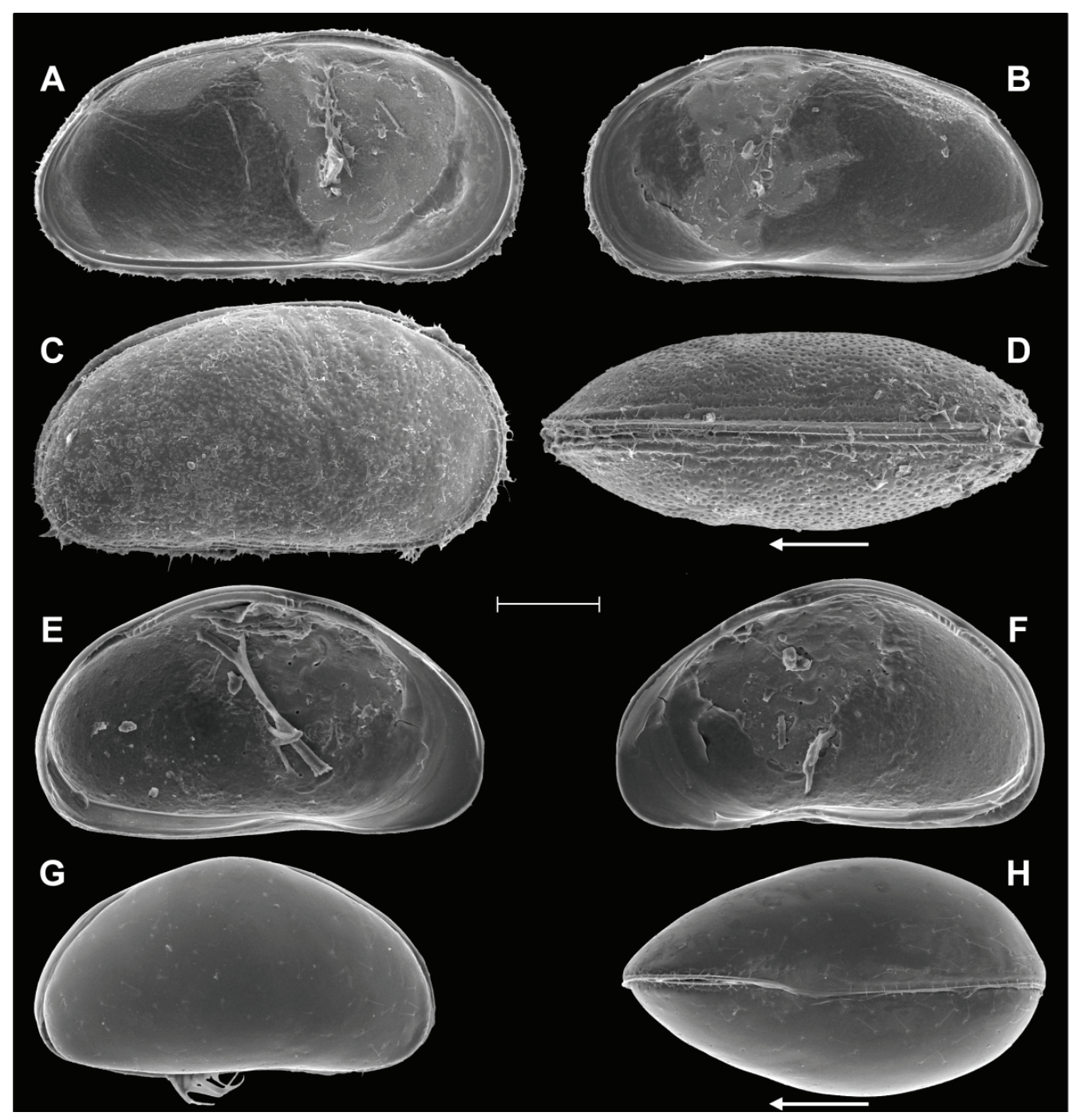

Plate 7. Cyprideis torosa (A-D); Xestoleberis sp. (E-H). All adult specimens. (A): VP1070, female, LV, iv; (B): idem, RV, iv; (C): VP1261, female, Cp, Rlv; (D): VP1262, female, Cp, vv; (E): VP0608, female, LV, iv; (F): idem, RV, iv; (G): VP0634, female, Rlv; (H): VP0635, female, Cp, vv. Scale bar: $200 \mu \mathrm{m}$ for A-C; $233 \mu \mathrm{m}$ for D-F.

Received: July 2008

Accepted: September 2008 